\title{
FAKTOR-FAKTOR YANG BERHUBUNGAN DENGAN MINAT BERWIRAUSAHA MAHASISWA PROGRAM STUDI AGRIBISNIS FAKULTAS PERTANIAN UNIVERSITAS GALUH
}

\author{
FACTORS RELATED TO STUDENT ENTREPRENEURIAL INTEREST IN \\ AGRIBUSINESS STUDY PROGRAM, FACULTY OF AGRICULTURE, GALUH \\ UNIVERSITY
}

\author{
VINA FANDINI ${ }^{1 *}$, DINI ROCHDIANI ${ }^{2}$ BUDI SETIA $^{1}$ \\ ${ }^{1}$ Fakultas Pertanian Universitas Galuh \\ ${ }^{2}$ Fakultas Pertanian Universitas Padjadjaran \\ "E-mail : vina.fandini@gmail.com
}

\begin{abstract}
ABSTRAK
Penelitian ini bertujuan untuk mengidentifikasi faktor-faktor yang berhubungan dengan minat berwirausaha mahasiswa Program Studi Agrbisnis Fakultas Pertanian Universitas Galuh. Sampel diambil dengan metode simple random sampling. Metode analisis data yang digunakan dalam penelitian ini adalah analisis Spearman Rank's dan uji t. Hasil penelitian menunjukan bahwa : Terdapat hubungan dengan tingkat kekuatan hubungan yang cukup, signifikan dan angka koefisien korelasinya bernilai positif antara ekspektasi pendapatan, pengetahuan kewirausahaan, dan lingkungan sosial dengan minat berwirausaha.
\end{abstract}

Kata Kunci : Pendapatan, Pengetahuan, Lingkungan Sosial, Minat berwirausaha,

\section{ABSTRACT}

This study aims to identify the factors related to the entrepreneurial interest of students of the Agriculture Study Program at the Faculty of Agriculture, Galuh University. Sampling was determined by simple random sampling method. Data analysis methods used in this study are Spearman Rank's analysis and t test. The results of the study show that: There is a relationship with the level of strength of the relationship that is sufficient, significant and the correlation coefficient value is positive between expectations income, entrepreneurial knowledge, and social environment with entrepreneurial interest.

Keywords: Expectations Income, Knowledge, Social Environment, Entrepreneurship Interest,

\section{PENDAHULUAN}

Kewirausahaan adalah proses dimana seorang individu atau kelompok menggunakan upaya tersusun dan alat untuk mengejar kemungkinan untuk menciptakan nilai dan tumbuh dengan memenuhi kebutuhan dan keinginan melalui keunikan dan inovasi, tentang masalah sumber daya apa yang dikendalikan saat ini (Robbins dan Coulter dalam Takdir, 2015).

Menurut Takdir (2015), karakter seorang wirausaha meliputi: memiliki kreatifitas tinggi, memiliki etos kerja, selalu komitmen dalam pekerjaan, dan tanggung jawab, mandiri, berani menghadapi risiko, motif berprestasi tinggi, selalu perspektif, perilaku inovatif 
tinggi, selalu mencari peluang, memiliki jiwa kepemimpinan, memiliki kemampuan manajerial, dan memiliki keterampilan personal.

Salah satu kegiatan usaha yang banyak dilakukan oleh para wirausahawan yaitu kegiatan usaha pertanian atau agribisnis. Menurut data Hasil Survei Pertanian Antar Sensus (SUTAS) (BPS, 2018), sektor pertanian merupakan bagian sentral yang memiliki bagian penting pada perekonomian nasional dalam menyerap tenaga kerja, penyumbang devisa, dan sumber pertumbuhan ekonomi. Selain itu, pertanian juga menjadi penggerak sektor lain dalam perekonomian nasional. Sedangkan agribisnis merupakan suatu kegiatan usaha kesatuan yang meliputi keseluruhan atau salah satu dari mata rantai produksi, pengolahan hasil, dan pemasaran yang luas, yaitu kegiatan usaha yang menunjang kegiatan pertanian dan kegiatan usaha yang ditunjukan oleh kegiatan pertanian (Soekartawi, 1993)

Sebagian ahli masih beranggapan bahwa agribisnis merupakan usaha kecil menengah (UKM), yaitu pedagang kaki lima dan petani gurem, sedangkan usaha industri adalah usaha modern di perkotaan, namun mereka lupa bahwa pengembangan sektor agribisnis identik dengan membangun desa, di mana $70 \%$ penduduk
Indonesia berada di perdesaan, dan merupakan pihak yang menopang industri di perkotaan sebagai konsumen (Pasaribu, 2012).

Jumlah tenaga kerja informal sektor pertanian pada tahun 2018 mencapai $88,27 \%$ hal ini mengindentifikasi bahwa peluang pekerjaan di sektor pertanian cukup tinggi. Sementara itu tingkat pengangguran terbuka berdasarkan tingkat pendidikan pada sekolah tinggi tahun 2018 berkisar $5,92 \%$ naik $0,35 \%$ dari tahun sebelumnya (BPS, 2019).

Untuk mendukung program pemerintah yang berkaitan dengan kewirausahaan, dan mendorong minat mahasiswa untuk berwirausaha, maka Fakultas Pertanian Universitas Galuh sebagai perguruan tinggi di Jawa Barat, mempunyai peran dan kewajiban untuk membekali para mahasiswanya dengan ilmu pengetahuan dan keterampilan yang berkaitan dengan kewirausahaan terutama di sektor agribisnis. Materi dan bahan ajarnya telah diarahkan untuk mendukung perkembangan wirausaha di bidang pertanian dengan harapan mahasiswa dan lulusannya dapat menjadi wirausaha muda terdidik yang mandiri dan bisa merintis usaha miliknya sendiri.

Selain itu, dengan menumbuhkan jiwa kewirausahaan para mahasiswanya di 
Fakultas Pertanian Universitas Galuh, maka, diharapkan dapat menjadi alternatif keluar untuk memperoleh pekerjaan (sebagai wirausahawan muda) dan mengurangi tingkat pengangguran, namun yang menjadi permasalahnya adalah sampai sejauh mana minat mahasiswa untuk menjadi calon wirausahawan, karena banyak faktor yang mempengaruhi minat untuk berwirausaha di kalangan mahasiswa.

Sebagai tahap pertama dalam usaha atau berwirausaha adalah dengan minat berwirausaha pada mahasiswa. Berdasarkan tingkat pendidikannya, Sarjana S1 berpotensi memiliki minat dalam berwirausaha, karena mahasiswa memiliki kemampuan keterampilan dan penalaran yang memadai. Adanya minat berwirausaha akan menjadikan seseorang lebih giat memanfaatkan dan mencari peluang usaha dengan memaksimalkan potensinya. Minat tidak dibawa sejak lahir tetapi tumbuh dan berkembang sesuai dengan faktor-faktor yang mempengaruhinya (Supriyono, 2006 dalam Cahyo, 2010).

Ekspektasi atau harapan atas pendapatan yang lebih baik merupakan salah faktor yang berpengaruh terhadap keinginan seseorang untuk berwirausaha. Jika seseorang berharap untuk menghasilkan pemasukan yang banyak dengan menjadi wirausaha, maka ia akan semakin terdorong untuk menjadi seorang wirausaha (Ismaya, 2018).

$$
\text { Menurut Hisrich }
$$

(2008), pengetahuan kewirausahaan adalah landasan dari sumber daya kewirausahaan yang ada di dalam diri individu; sedangkan menurut Suryana (2009), pengetahuan kewirausahaan adalah pengetahuan yang ada pada manusia sangat diperlukan terutama untuk: memproduksi barang atau jasa baru, menghasilkan nilai tambah baru, merintis usaha baru, perlakuan proses/teknik baru, mengembangkan organisasi baru.

Lingkungan sosial menurut Stroz (1987) dalam Oktorina (2018) meliputi semua kondisi yang ada di dunia yang dalam kondisi tertentu mempengaruhi prilaku manusia, termasuk pertumbuhan dan perkembangan atau life process, yang dilihat sebagai penyiapan lingkungan (to provide environment) bagi keturunan selanjutnya.

Berdasarkan uraian di atas, maka dalam penelitian ini penting untuk dikaji mengenai faktor-faktor apa saja yang berhubungan dengan minat berwirausaha mahasiswa Program Studi Agribisnis Fakultas Pertanian Universitas Galuh. 
Penelitian ini dilakukan untuk mengidentifikasi apa saja yang menjadi faktor-faktor yang berhubungan dengan minat berwirausaha mahasiswa Program Studi Agribisnis Fakultas Pertanian Universitas Galuh.

\section{METODE PENELITIAN}

\section{Tempat dan Waktu Penelitian}

Penelitian ini dilakukan di Fakulats Pertanian Universitas Galuh Ciamis. Waktu Penelitian terdiri atas 3 tahap : (1) tahap Persiapan pada bulan Maret 2019 (2) Tahap Pelaksanaan Penelitian dilaksanakan pada bulan Juni 2019 (3) Tahap Pengolahan data dilaksanakana pada bulan Juli 2019 sampai dengan selasai.

\section{Teknik Pengumpulan Data}

Teknik Penelitian yang dilakukan adalah survey, yaitu analisis yang dilakukan untuk mendapat bukti dari fenomena yang ada dan mencari informasi nyata, baik tentang institusiekonomi, sosial, atau politik dari suatu daerah atau kelompok. Teknik penarikan sampel yaitusimple random sampling, merupakan metode penarikan sampel probabilitas yang dilaksanakan dengan acak sederhana. Penentuan responden dilakukan dengan rumus slovin dan didapat hasil 84 orang sampel untuk mahasiswa angkatan 2015, 2016, 2017 dan 2018.
Data yang dipakai adalah data primer, yaitu data yang diperoleh secara langsung dari responden dengan mengisi kuesioner dan data sekunder adalah data yang diambil dari bagian akademik prodi agribisnis, studi literatur dan penelitian terdahulu.

\section{Rancangan Analisis Data}

Untuk mengetahui tingkat variabel pendapatan, pengetahuan kewirausahaan, lingkungan sosial dan minat berwirausaha dibagi kedalam 3 kategori yaitu tinggi, sedang, dan rendah serta dilakukan analisis secara deskriptif.

PK Interval $=\frac{\text { Rentang }}{\text { Banyak Kelas }}$

Keterangan : Rentang = Nilai Maksimal Nilai Minimal

\section{Banyak Kelas = Jumlah Kategori}

$\mathrm{Pk}$ interval $=\frac{\text { Rentang }}{\text { Banyak Kelas }}$

X1

$$
=\frac{15-3}{3}
$$

$$
=4
$$

1) Rendah $: 3,00 \leq Q \leq 7,00$

2) Sedang $: 7,00<Q \leq 11,00$

3) Tinggi $: 11,00<\mathrm{Q} \leq 15,00$

$\mathrm{X} 2, \mathrm{X} 3, \mathrm{Y}=\frac{25-5}{3}$

$$
=6,67
$$

1) Rendah $: 5,00 \leq \mathrm{Q} \leq 11,66$

2) Sedang $: 11,66<Q \leq 18,33$

3) Tinggi $: 18,33<Q \leq 25,00$

Penyebaran skor untuk X1 adalah 3 indikator dan untuk variabel X2, X3, dan Y 
adalah sama,setiap variabel terdiri atas 5 indikator pertanyaan dengan menggunakan skala Likert dengan kisaran skor 1-5.

\section{Uji Instrumen Penelitian}

Uji insturmen penelitian dilakukan dengan :

\section{Uji Validitas}

Uji validitas adalah untuk mengukur kevalidan kuesioner yang digunakan (Ghozali, 2006). Suatu instrumen tidak bisa valid untuk sembarang keperluan atau kelompok; suatu instrumen hanya valid untuk suatu keperluan dan pada kelompok tertentu (Sumanto, 2014) :

Pengujian validitas dilakukan berdasarkan analisis item yaitu mengkorelasikan skor setiap item dengan skor variabel (hasil penjumlahan seluruh item pertanyaan). Teknik korelasinya memakai pearson correlation, dihitung memakaiSPSS 17. Validitas dihitung dengan membandingkana antara $r$ hitung dengan $r$ tabel. Jika $r$ hitung lebih besar dari $r$ tabel maka pernyataan tersebut valid.

2. Uji Reliabilitas

Uji reabilitas merupaka uji yang digunakan untuk mengukur variabel tyang digunakan untuk penelitian. Suatu kuesioner yang reliabel atau handal jika jawaban Responden terhadap pertanyaan adalah konsisten atau stabil setiap saat (Ghozali, 2011).
Reliabilitas instrumen penelitian diuji menggunakan rumus koefisien Cronbach's Alpha pada instrumen dari masing-masing variabel yang diuji. Menurut Nunnaly dalam Ghozali (2011) Ketika Alpha $>0,60$ variabel penelitian itu dikatakan handal.

\section{Teknik Analisis Data}

Dalam penelitian kualitatif ini menggunakan statistik inferensial non parametrik.

\section{Spearman Rank's Corelation}

Uji korelasi yang sesuai dengan data adalah uji Korelasi Spearman Rank. Korelasi iniuntuk menguji associative correlationjika variabel yang dihubungkan bentuknya ordinal, dan data sumber variabel tidak perlu sama (Sugiyono, 2002).

Untuk mengukur korelasi antara ekspektasi pendapatan, pengetahuan kewirausahaan dan lingkungan sosial dengan minat berwirausaha mahasiswa Prodi Agribisnis Faperta Universitas Galuh dapat digunakan rumus sebagai berikut:

Untuk pengujiannya digunakana uji $\mathrm{t}$ (Sugiyono, 2012) dengan rumus sebagai berikut:

$t=r_{s} \sqrt{\frac{N-2}{1-\left(r_{s}\right)^{2}}}$

keterangan :

$\mathrm{t}=\mathrm{t}$ hitung 
$\mathrm{N} \quad=$ Data observasi

$\mathrm{r}_{\mathrm{s}} \quad=$ Korelasi Spearman Rank's

Dengan signifikansi $95 \%$

1. Merumuskan Hipotesis

$\mathrm{H}_{0} \quad: \rho=0$ “Tidak terdapat hubungan yang signifikan variabel $\mathrm{X}$ terhadap Y”

$\mathrm{H}_{\mathrm{a}} \quad: \rho \neq 0$ “Terdapat hubungan yang signifikan variabel $\mathrm{X}$ terhadap $\mathrm{Y}$ ”

2. Kriteria Penerimaan hipotesis

Jika sig $<0,05$ maka $\mathrm{H}_{\mathrm{a}}$ diterima

Jika sig > 0,05 maka $\mathrm{H}_{\mathrm{a}}$ ditolak

Jika hasilnya signifikan, untuk melihat korelai hubungan variabelnya, bisa juga digunakan skala Guilford, menurut Sugiyono (2002) sebagai berikut :

a) $0.00 \mathrm{~s} / \mathrm{d} \quad 0.20$ : hubungan sangat kecil dan bisa diabaikan

b) $0.21 \mathrm{~s} / \mathrm{d} 0.40$ :hubungan sangat kecil

c) $0.41 \mathrm{~s} / \mathrm{d}$ 0.70: hubungan cukup kuat

d) $0.71-0.90$ :hubungan kuat

e) 0,91 - 1,00: hubungan sangat kuat

\section{HASIL DAN PEMBAHASAN}

\section{Karakteristik Responden}

Identitas yang dibahas dalam penelitian ini meliputi jenis kelamin, umur, pekerjaan orangtua, dan pengalaman berwirausaha.

Komposisi jenis kelamin responden bahwa responden laki-laki dengan persentase $55 \%$ (48 orang) lebih banyak dibandingkan dengan responden perempuan sebanyak $45 \%$ (36 orang).

Responden dengan rentang umur 2021 tahun memiliki persentase tertinggi yakni $46 \%$ (39 orang) dikuti responden dengan usia lebih dari sama dengan 22 tahun sebanyak 38\% (32 orang) dan usia antara 18-19 tahun 15\% (13 orang).

Mayoritas pekerjaan orangtua responden adalah bukan wirausaha sebanyak $57 \%$ atau 48 orang dan sisanya bekerja sebagai wirausaha sebanyak $43 \%$ atau 36 orang.

Serta mayoritas Responden tidak pernah berwirausaha sebanyak 46 orang atau $55 \%$ dan sebanyak 38 orang atau $45 \%$ menyatakan pernah berwirausaha.

Uji Validitas yang dilakukan dengan menggunakan SPSS 17 menyatakan bahwa semua butir pertanyaan dalam kuesioner menunjukan hasil yang valid, hasil dapat dilihat pada tabel 1 . 
Tabel 1. Uji Validitas

\begin{tabular}{|c|c|c|c|c|}
\hline \multirow{2}{*}{$\begin{array}{l}\text { Indikator } \\
\text { Variabel }\end{array}$} & \multicolumn{2}{|l|}{15} & 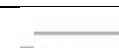 & \multirow{2}{*}{ Ket } \\
\hline & thitung & $\mathrm{r}_{\text {tab }}$ & Ftidit Ket & \\
\hline X1.P1 & 0,678 & & 0,2146 & Valid \\
\hline X1.P2 & 0,854 & & 0,2146 & Valid \\
\hline X1.P3 & 0,800 & & 0,2146 & Valid \\
\hline X2.P1 & 0,705 & & 0,2146 & Valid \\
\hline $\mathrm{X} 2 . \mathrm{P} 2$ & 0,656 & & 0,2146 & Valid \\
\hline X2.P3 & 0,594 & & 0,2146 & Valid \\
\hline $\mathrm{X} 2 . \mathrm{P} 4$ & 0,586 & & 0,2146 & Valid \\
\hline X2.P5 & 0,755 & & 0,2146 & Valid \\
\hline X3.P1 & 0,676 & & 0,2146 & Valid \\
\hline X3.P2 & 0,673 & & 0,2146 & Valid \\
\hline X3.P3 & 0,758 & & 0,2146 & Valid \\
\hline X3.P4 & 0,745 & & 0,2146 & Valid \\
\hline X3.P5 & 0,549 & & 0,2146 & Valid \\
\hline Y.P1 & 0,700 & & 0,2146 & Valid \\
\hline Y.P2 & 0,645 & & 0,2146 & Valid \\
\hline Y.P3 & 0,792 & & 0,2146 & Valid \\
\hline Y.P4 & 0,750 & & 0,2146 & Valid \\
\hline Y.P5 & 0,689 & & 0,2146 & Valid \\
\hline
\end{tabular}

Setelah semua item soal valid maka dapat dilakukan uji reliabilitas dengan menggunakan SPSS 17, hasil dapat dilihat pada tabel 2, dan dinyatakan reliabel/handal sehingga analisis data dapat dilakukan.

Tabel 2. Uji Reliabilitas

\begin{tabular}{lccc}
\hline \multicolumn{1}{c}{ Variabel } & $\begin{array}{c}\text { Cronbach } \\
\text { 's Alpha }\end{array}$ & $\begin{array}{c}\text { Nilai } \\
\text { Minimum }\end{array}$ & Keterangan \\
\hline $\begin{array}{l}\text { Pendapatan } \\
\text { (X1) }\end{array}$ & 0,668 & 0,60 & Reliabel \\
$\begin{array}{l}\text { Pengetahuan } \\
\text { Kewirausahaa } \\
\text { (X2) }\end{array}$ & 0,670 & 0,60 & Reliael \\
$\begin{array}{l}\text { Lingkungan } \\
\text { Sosial (X3) } \\
\text { Minat } \\
\text { Berwirausaha } \\
(Y)\end{array}$ & 0,710 & 0,60 & Reliabel \\
\hline
\end{tabular}

\section{Tingkat Variabel}

Berdasarkan data yang diperoleh dari penelitian diketahui bahwa variabel ekspektasi pendapatan termasuk ke dalam kategori tinggi, dengan rata-rata total skor berada di kisaran $11,00<\mathrm{Q} \leq 15,00$ dengan Q adalah 13,464.

Tabel 3. Tingkat Variabel ekspektasi Pendapatan

\begin{tabular}{|c|c|c|c|c|}
\hline No & Kategori & Kisaran Skor & Jumlah (Orang) & Persentase \\
\hline 1 & Tinggi & $11,00<Q \leq 15,00$ & 82 & 97,6 \\
\hline 2 & Sedang & $7,00<Q \leq 11,00$ & 2 & 2,4 \\
\hline 3 & Rendah & $3,00 \leq Q \leq 7,00$ & 0 & 0 \\
\hline \multicolumn{3}{|c|}{ Jumlah } & 84 & 100,0 \\
\hline
\end{tabular}

Tabel 3 menunjukan bahwa responden yakin bahwa dengan berwirausaha pendapatan yang diterima lebih besar, lebih tinggi dibandingkan bekerja pada orang lain, pendapatan sendiri, klaim kekayaan bisnis dan ekspektasi pendapatan yang tinggi.

Ekspektasi atau harapan atas penghasilan seseorang akan semakin terdorong dengan menjadi seorang wirausaha penghasilannya lebih tinggi daripada dengan bekerja pada orang lain (Ismaya, 2018).

Berdasarkan data yang diperoleh dari penelitian diketahui bahwa variabel pengetahuan kewirausahaan tinggi, dengan rata-rata total skor berada di kisaran 18,34 $<\mathrm{Q} \leq 25,00$ dengan $\mathrm{Q}$ adalah 21,25. 
Tabel 4. Tingkat Variabel Pengetahuan Kewirausahaan

\begin{tabular}{|c|c|c|c|c|}
\hline No & Kategori & Kisaran Skor & Jumlah (Orang) & Persentase \\
\hline 1 & Tinggi & $18,33<\mathrm{Q} \leq 25,00$ & 81 & 96,4 \\
\hline 2 & Sedang & $11,66<\mathrm{Q} \leq 18,33$ & 3 & 3,6 \\
\hline 3 & Rendah & $5,00 \leq Q \leq 11,66$ & 0 & 0 \\
\hline \multicolumn{3}{|c|}{ Jumlah } & 84 & 100,0 \\
\hline
\end{tabular}

Tabel 4 menunjukan bahwa sebanyak 96,4 persen atau 81 responden memiliki ketertarikan dalam pengetahuan kewirausahaan yang tinggi. Sementara sisanya masuk ke dalam kategori sedang sebanyak 3,6 persen atau 3 orang.

Pengetahuan yang dimiliki oleh seseorang sangat diperlukan terutama untuk; menghasilkan produk barang atau jasa baru,menghasilkan nilai tambah baru, merintis usaha baru, perlakuan atau teknis baru, dan mengembangkan orgnisasi baru (Suryana, 2009)

Berdasarkan data yang diperoleh dari penelitian diketahui bahwa variabel lingkungan sosial tinggi, dengan rata-rata total skor berada di kisaran $18,34<\mathrm{Q} \leq$ 25,00 dengan Q adalah 21,39.

Tabel 5. Tingkat Variabel Lingkungan Sosial

\begin{tabular}{|c|c|c|c|c|}
\hline No & Kategori & Kisaran Skor & Jumlah (Orang) & Persentase \\
\hline 1 & Tinggi & $18,34<\mathrm{Q} \leq 25,00$ & 77 & 91,7 \\
\hline 2 & Sedang & $11,67<Q \leq 18,33$ & 7 & 8,3 \\
\hline 3 & Rendah & $5,00 \leq Q \leq 11,66$ & 0 & 0 \\
\hline \multicolumn{3}{|c|}{ Jumlah } & 84 & 100,0 \\
\hline
\end{tabular}

Tabel 5 menunjukan bahwa sebanyak 91,7 persen atau 77 responden setuju bahwa lingkungan sosial memiliki peran tinggi dalam menarik keinginan mahasiswa untuk berwirausaha. Sementara sisanya masuk ke dalam kategori sedang sebanyak 8,3 persen atau 7 orang.

Lingkungan meliputi tingkah laku, pertumbuhan, perkembangan, proses kehidupan dan kondisi dimana semuanya mempengaruhi tingkah laku seseorang

Berdasarkan data yang diperoleh dari penelitian diketahui bahwa variabel minat berwirausaha tinggi, dengan rata-rata total skor berada di kisaran $18,34<\mathrm{Q} \leq$ 25,00 dengan Q adalah 22,03.

Tabel 6. Tingkat Variabel Minat Berwirausaha

\begin{tabular}{|c|c|c|c|c|}
\hline No & Kategori & Kisaran Skor & Jumlah (Orang) & Persentase \\
\hline 1 & Tinggi & $18,34<Q \leq 25,00$ & 79 & 94,0 \\
\hline 2 & Sedang & $11,67<Q \leq 18,33$ & 5 & 6,0 \\
\hline 3 & Rendah & $5,00 \leq Q \leq 11,66$ & 0 & 0 \\
\hline \multicolumn{3}{|c|}{ Jumlah } & 84 & 100,0 \\
\hline
\end{tabular}

Tabel 6 menunjukan bahwa sebanyak $94 \%$ atau 79 responden memiliki minat yang tinggi untuk berwirausaha. Rasa ketertarikan dalam berwirausaha yang bersedia untuk tekun dan bekerja keras untuk sukses dalam usahanya, karena minat berkembang sesuai dengan faktorfaktor yang mempengaruhi. (Bygrave, 2003). Sementara sisanya masuk ke dalam kategori sedang sebanyak $6 \%$ atau 5 orang.

Hasil outuput penelitian yang disajikan pada tabel 7,menunjukannilai $r_{s}$ 
yang diperoleh dari kategori ekspektasi pendapatan dengan minat berwirausaha adalah 0,544. Menurut Sugiyono (2002) nilai $r_{\mathrm{s}}$ tersebut memiliki tingkat kekuatan hubungan yang cukup kuat dan angka koefisien korelasinya bernilai positif. Sedangkan hasil pengujian hipotesis menunjukan angka 5,818 yang lebih besar dari t tabel (a 0,05) yaitu sebesar 2,637, sehingga $\mathrm{H}_{\mathrm{a}}$ diterima.

Tabel 7. Hasil Variabel ekspektasi Pendapatan

\begin{tabular}{|l|c|c|c|c|c|}
\hline $\begin{array}{c}\text { Hasil } \\
\text { Variabel }\end{array}$ & $\mathrm{r}_{\mathrm{s}}^{\text {'ex }}$ & $\mathrm{t}_{\text {tuang }}^{\text {patan }}$ & $\mathrm{t}_{\text {mber }}$ & $\begin{array}{c}\text { Kekn } \\
\text { Hubu }\end{array}$ & $\begin{array}{c}\text { Kekuatan } \\
\text { Hubungan }\end{array}$ \\
\hline $\begin{array}{l}\text { X1 } \\
\text { dengan Y }\end{array}$ & 0,544 & $5,942 *$ & 2,637 & $\begin{array}{c}\text { Cukup } \\
\text { kuat }\end{array}$ \\
\hline
\end{tabular}

Ket: $t_{\text {hitung }}$ dengan tanda ${ }^{*}$ memperoleh hubungan positif menggunakan uji Rank Spearman dengan taraf signifikansi 5\%

Hasil analisis hubungan variabel pendapatan dengan minat berwirausaha memiliki tingkat hubungan yang cukup kuat, signifikan dan berkorelasi positif. Hasil penelitian ini didukung hasil penelitian Putra (2018) yang menunjukan bahwa ekspektasi pendapatan mempunyai pengaruh yang positif terhadap minat berwirausaha yang artinya apabila ekspektasi pendapatannaik, minat berwirausaha akan meningkat. Minat berwirausaha dengan ekspektasi pendapatan lebih dari pedapatan bekeraj pada orang lain merupakan faktor pendorong seorang mahasiswa menjadi wirausahawan. Tetapi, akan lebih baik jika dengan berwirausaha, mahasiswa tersebut menjadikan itu sebagai tempat menambah wawasan sekaligus mencari pengalaman.

Hasil outuput penelitian yang disajikan pada tabel 8menunjukannilai $\mathrm{r}_{\mathrm{s}}$ yang diperoleh dari kategori Pengetahuan kewirausahaan dengan minat berwirausaha adalah 0,503. Menurut Sugiyono (2002) nilai $\mathrm{r}_{\mathrm{s}}$ tersebut memiliki tingkat kekuatan hubungan yang cukup kuat dan angka koefisien korelasinya bernilai positif. Sedangkan hasil pengujian hipotesis menunjukan angka 5,270 yang lebih besar dari t tabel (a 0,05) yaitu sebesar 2,637, sehingga $\mathrm{H}_{\mathrm{a}}$ diterima.

\section{Tabel 8. Hasil Variabel Pengetahuan} Kewirausahaan

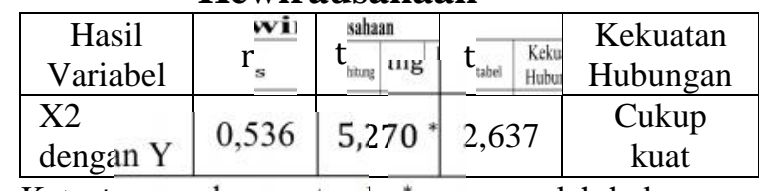

Ket: $t_{\text {hitung }}$ dengan tanda ${ }^{*}$ memperoleh hubungan positif menggunakan uji Rank Spearman dengan taraf signifikan 5\%

Hasil analisis hubungan antara variabel pengetahuan kewirausahaan dengan minat berwirausaha memiliki tingkat hubungan yang cukup kuat, signifikan dan berkorelasi positif. Penelitian ini didukung penelitian Yuliyaningsih (2013), Dimana Pengetahuan kewirausahaan menunjukan 
hubungan signifikan dan positif terhadap minat. Menurut Zimmer, et al (2008) banyak akademisi dan universitas yang dihantui oleh berkurangnya kesempatan kerja di perusahan-perusahaan dan jalur karir yang kurang menjanjikan, membuat jumlah mahasiswa yang menginginkan usahasendiri sebagai karir meningkat dengan cepat. Hasil yang sama ditunjukan pada penelitian Umi (2015) bahwa Pengetahuan kewirausahaan berpengaruh positif dan signifikan terhadap minat berwirausaha mahasiswa. Menurut Trisnawati (2014) dengan pengetahuan yang memadai dan cukup menjadi salah satu aspek penting dari pengetahuan kewirausahaan untuk pengembangan usahanya dengan baik.

Hasil outuput penelitian yang disajikan tabel 9,menunjukannilai $r_{\mathrm{s}}$ yang diperoleh dari kategori lingkunagn sosial dengan minat berwirausaha adalah 0,582, menurut Sugiyono (2002) nilai $r_{s}$ tersebut memiliki tingkat kekuatan hubungan yang cukup kuat dan angka koefisien korelasinya bernilai positif. Sedangkan hasil pengujian hipotesis menunjukan angka 6,482 yang lebih besar dari t tabel ( $a$ 0,05) yaitu sebesar 2,637, sehingga $\mathrm{H}_{\mathrm{a}}$ diterima.
Tabel 9. Hasil Variabel Lingkungan Sosial

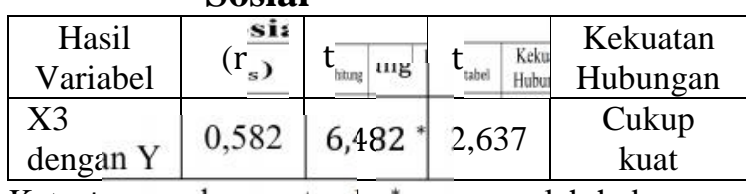

Ket: $t_{\text {hitung }}$ dengan tanda * memperoleh hubungan positif menggunakan uji Rank Spearman dengan taraf signifikan 5\%

Hasil analisis hubungan antara variabel lingkungan sosial dengan minat berwirausaha memiliki tingkat hubungan yang cukup kuat, signifikan dan berkorelasi positif. Penelitian ini didukung oleh Putra (2018) yang menyatakan bahwa lingkungan keluarga berpengaruh terhadap minat berwirausaha. Lingkungan keluarga sangat diperlukan untuk menumbuhkan minat dan semangat seorang mahasiswa untuk menjadi wirausaha muda yang sukses. Hasil yang sama ditunjukan oleh penelitian Umi (2014) menyatakan bahwa lingkungan berpengaruh positif dan signifikan terhadap minat berwirausaha. Menurut Slameto (2015) cara orangtua mendidik dan relasi antar keluarga berpengaruh terhadap minat. Metode belajar juga mempengaruhi proses belajar, diharapkan mahasiswa dapat menerima, menguasai, dan menumbuhkan bahan pelajaran dengan cara yang tepat, efisien dan efektif. Lingkungan masyarakat mempengaruhi dengan adanya kegiatan dan interaksi baik antar sesama manusia maupun melalui media massa termasuk 
didalamnya teman bergaul, yang memiliki pengaruh cepat dalam kehidupan bermasyarakat.

\section{KESIMPULAN DAN SARAN}

\section{Kesimpulan}

Hasil uji analisis yang telah dilakukan dengan menggunakan teknik korelasi Spearman Rank's, menghasilkan kesimpulan sebagai berikut:

1. Terdapat hubungan dengan tingkat kekuatan hubungan yang cukup kuat, signifikan, dan angka koefisien korelasinya bernilai positif antara faktor ekpektasi pendapatan, pengetahuan kewirausahaan, dan lingkungan sosialdengan minat berwirausaha Mahasiswa Program Studi Agribisnis Fakultas Pertanian Universitas Galuh.

\section{Saran}

Berdasarkan hasil penelitian dan pembahasan yang telah dikemukan diatas, maka saran yang dapat diajukan adalah agar penelitian dapat dijadikan pertimbangan yang mempengaruhi minat mahasiswa dalam berwirausaha yang didasarkan pada pandangan ekspektasi pendapatan, pengetahuan kewirausahaan dan lingkungan sosial. Sehingga dapat menyiapkan individu dengan memberikan pendidilan dini terhadap generasi muda tentang wirausaha, agar dikemudian hari lahir pelaku-pelaku usaha baru yang mampu mengembangkan potensi yang ada.

\section{DAFTAR PUSTAKA}

Adhitama, Paulus Patria. 2014. FaktorFaktor Yang Mempengaruhi Minat Berwirausaha. (Studi Kasus Mahasiswa Fakultas Ekonomi dan Bisnis Undip, Semarang.Universitas

Diponegoro Semarang). Skripsi.

Bygrave, W. D. 2003. The Portable MBA Entrepreneurship. Aksara. Jakarta. Binarupa.

Cahyo, Antonius Chandra Tri. 2010. Analisis Faktor-Faktor yang Mempengaruhi Minat Berwirausah pada Mahasiwa (Studi Kasus : Mahasisw/I Fakultas Ekonomi Jurusan Manajemen Universitas Sanata Dharma) .Program Studi Manajemen Jurusan Manajemen Fakultas Ekonomi Universitas Sanata Dharma Yogyakarta. Skirpsi.

Ghozali, Imam. 2006. Aplikasi Analisis Multivariate dengan program SPSS Cetakan Keempat. Badan Penerbit Universitas Diponegoro. Semarang

Hisrich, Robert D et al. 2008. Entrepreneurship $\quad\left(7^{\text {th }} e d\right)$. McGraw Hill. Singapore.

Ismaya, Seva. 2018. Pengaruh Kemandirian Pribadi, Ekspektasi Pendapatan, dan Pendidikan Kewirausahaan Siswa Muslim di UPT Pelatihan Kerja Tulungagung. IAIN Tulungagung.Skripsidipublikasikan. 
Mu'alimah, Umi. 2015. Analisis Pengaruh Faktor Motivasi, Lingkungan dan Pengetahuan Terhadap Minat Wirausaha Mahasiswa (Studi Kasus pada Koperasi Mahasiswa Tahun 2014). Skirpsi, Jurusan Syariah dan Ekonomi Islam Program Studi Perbankan Syariah, Institut Agama Islam Negeri Salatiga.

Oktorina, Trivena. 2018. Pengaruh Disiplin Belajar dan Lingkungan Sosial Terhadap Prestasi Belajar Mahasisawa Program Studi Pendidikan Ekonomi Universitas Sanata Dharma.FKIP Universitas Snata Dharma Yogyakarta. Skripsidipublikasikan.

Pasaribu, H. Ali Musa. 2012. Kewirausahaan Berbasis Agribisnis. Penerbit Andi. Yogyarakta.

Putra, Irsan Darma. 2018. Analisis FaktorFaktor yang Mempengaruhi Minat Berwirausaha Mahasiswa Fakultas Ekonomi Universitas Islam Indonesia. UII Yogyakarta. P.ISSN : 19786751.

Slameto. 2015. Belajar dan Faktor-Faktor yang Mempengaruhinya. Rineka Cipta. Jakarta.

Soekartawi. 1993. Agribisnis Teori dan Aplikasinya. Raja Grafindo Persada. Jakarta.
Sugiyono. 2002.Metode Penelitian Bisnis. Alfabeta. Bandung. . 2012. Metode Penelitian Bisnis. Alfabeta. Bandung.

Sumanto. 2014. Statistika Terapan. CAPS. Yogyakarta.

Suryana. 2009. Kewirausahaan, Pedoman Praktis: Kiat dan Proses Menuju Sukses. Salemba Empat. Jakarta.

Takdir, Dedy dkk. 2015. Kewirausahaan. Wijana Mahardi Karya. Yogyakarta.

Trisnawati, Novi. 2014. Pengaruh Pengetahuan Kewirausahan dan Dukungan Sosial Keluarga pada Minat Berwirausaha Siswa SMK Negeri 1 Pamekasan. Jurnal Ekonomi dan Pendidikan dan Kewirausahaan Unesa Volume . 2 Nomor. 1, Tahun 2014.

www.BPS.go.id diakses pada 19 Februari 2019.

Yuliyaningsih, Ika Pin., Susilaningsih dan Jaryanto. 2013. Hubungan Pengetahuan Kewirausahaan dan Persepsi Peluang Kerja di Bidang Akuntansi dengan Minat Berwirausaha. Jupe UNS vol. 2, No. 1, Hal 131-145.

Zimmerer, Thomas W et al. 2008. Kewirausahaan dan Manajemen Bisnis Kecil Edisi 5 buku 1. Salemba Empat. Jakarta. 